been obtained. The $F \alpha_{2}$ is identified with acetate fraction 5 , which is located in the same acetate band as fraction 6 , but forms the more anterior portion of the band. Fractions 6 and 9 are interpreted as haptoglobulins, but this still remains subject to question. Fraction 9 might also be interpreted as an $\alpha_{2}-\beta$ type globulin, similar to that described by Poulik and Smithies ${ }^{5}$, for human serum. Fraction 2, which has the same mobility as the main albumin band, is identified as an $\alpha_{1}$-globulin. The fact that it has exactly the same mobility as the albumin would suggest it to be similar in nature to the $\alpha_{1}$.globulin $B$ of Poulik and Smithies.

Department of Zoology,

E. J. DURE

Queen's University, Belfast.

'Kohn, J., Clin. Chim. Acta, 3, 450 (1958).

2 Aronsson, T., and Grönwall, A., Scand. J. Clin. Lab. Invest., 10, 318 (1958). Smithies, O., Binchem. J., 61, 629 (1955).

- Poulik, M. D., Nature, 180, 1477 (1957).

'Poulik, M. D., and Smithies, O., Biochem. J., 68, 636 (1958).

\section{Effect of Linoleic Acid on the Deposition of Dietary-saturated Fatty Acids in Chicken Tissues and Eggs}

KAUNITZ et al. have postulated that linoleate functions in the regulation of fatty acid composition of depot fat by facilitating the laying down of depot fat more representative of the diet ${ }^{1}$. In confirmation of their report, we have observed that the depot fat of chickens fed a diet with 5 per cent laurate and 4 per cent myristate contained higher proportions of these fatty acids when linoleate was added to the diet ${ }^{2}$. However, we could not adequately measure the effect of linoleate on the proportion of laurate and myristate in other, non-adipose tissues. In the work described here 12 per cent methyl laurate was included in a purified diet (diet $C-21$, Table 1) with and without a source of linoleate. The diets were fed to 7-day-old chicks maintained previously on a low fat diet. At several timeintervals the chickens were fasted overnight, killed, and the liver and heart analysed for fatty acids using gas chromatography ${ }^{3}$.

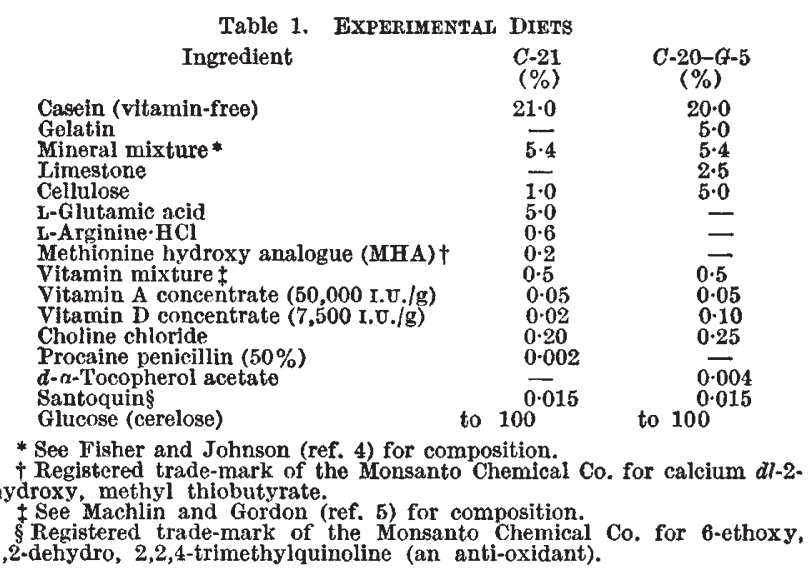

In a second experiment, White Leghorn hens were fed a purified basal diet (diet $C-20-G-5$, Table 1). Two levels of methyl myristate were added with and without a source of linoleic acid. Eggs were collected after 112 days on this régime and analysed for fatty acids. Five or six replicates per analysis were conducted.

The results given in Table 2 demonstrate that the liver and heart of chickens fed diets containing linoleic acid contained a higher proportion of laurate than chicks fed linoleate-free diets. Dietary linoleate resulted in an increased proportion of myristate in eggs laid by hens fed myristate. One would expect an increased proportion of
Table 2. EFfect of Dietary InNoleto AcID ON THE Deposition OF Table 2. EFFECT OF DIETARY IINOLEIC ACID ON TH
SHORT CHAIN FATTY ACIDS IN TISSUES

\begin{tabular}{|c|c|c|c|c|}
\hline Tissue & $\begin{array}{l}\text { Duration } \\
\text { of feeding } \\
\text { (days) }\end{array}$ & & \multicolumn{2}{|c|}{$\begin{array}{l}\text { Dietary linoleic acid* } \\
0 \% \\
1.5 \%\end{array}$} \\
\hline & & $\operatorname{diet}(C-21)$ & \multicolumn{2}{|c|}{$\begin{array}{l}\text { Lauric acid } \\
\% \text { of tissue fat } \dagger\end{array}$} \\
\hline $\begin{array}{l}\text { Liver } \\
\text { Liver } \\
\text { Heart }\end{array}$ & $\begin{array}{r}4 \\
39 \\
12\end{array}$ & $\begin{array}{l}11 \cdot 4 \\
11.4 \\
11 \cdot 4\end{array}$ & $\begin{array}{l}0.3 \pm 0.2 \\
1.2 \pm 0.2 \\
2.0 \pm 0.5\end{array}$ & $\begin{array}{l}0.9 \pm 0 \\
3 \cdot 8 \pm 0 \\
5 \cdot 0 \pm 1\end{array}$ \\
\hline
\end{tabular}

$$
\begin{aligned}
& \% \text { of } \operatorname{diet}(C-20-G-5)^{\text {Myristic acid }} \% \text { of egg fat }
\end{aligned}
$$

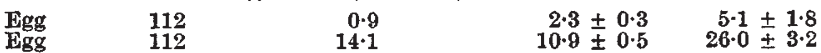

laurate and/or myristate in tissue lipids if addition of linoleic acid resulted in: (1) increased absorption of dietary laurate and myristate from the intestine; (2) decreased oxidation of these fatty acids; (3) altered mem. brane permeability in ovary, liver, or heart cells resulting in greater uptake of laurate and myristate from the blood.

Mead et al. ${ }^{6}$ have reported that essential fatty acid deficient mice oxidize stearate at a higher rate and incorporate less stearate in their tissue lipid than mice fed a source of essential fatty acids. More work is necessary before the biochemical mechanism underlying the change in saturated fatty acid composition following ingestion of linoleate can be defined.

Lawrence J. Machlin

Laboratory of Biochemistry and Nutrition, Monsanto Chemical Co., St. Louis, Mo.

I Kaunitz, H., Slanetz, C. S., Johnson, R. E., and Babayan, V. K., J. Nutrit., 73, 386 (1961).

${ }^{2}$ Machlin, L. J., and Gordon, R. S., J. Nutrit., 75, 157 (1961).

Marco, G. J., Machlin. L. J., Emery, E., and Gordon, R. S., Arch. Bicchem. Biophys., 90, 115 (1961).

- Fisher, H., and Johnson, D. J., J. Nutrit., 60, 261 (1956).

'Machlin, L. J., and Gordon, R. S., Poultry Sci., 37, 1460 (1958).

- Mead, J. F., Slaton, jun., W. H., and Decker, A. B., J. Biol. Chem., 218, 401 (1956).

\section{Distribution of Radioactive Sulphur after Oral Administration to the Rat of a Water-insoluble Fraction of Sulphur-35-labelled Thermal Amino- Acid Copolymer}

THE preparation of amino-acid copolymer labelled with sulphur-35 by thermal polymerization of hydrolysates of yeast (Torula utilis) incubated with ${ }^{35} \mathrm{SO}_{4}$ has already been described by us $^{1}$. The polymerization resulted in at least two different types of copolymers. One part of the preparation was absolutely insoluble in distilled water, while the other part could be dissolved in water. Both fractions showed protein-positive colour reactions and radioactivity.

By chromatography on ion exchange columns ${ }^{85} \mathrm{~S}$ activity could be observed at the positions of cysteic acid (sulphate) and methionine. The radioactivity of the cystine peak was very low. Another radioactive component could be eluted from the $150 \mathrm{~cm}$ 'Dowex 50 ' column by 0.2 $\mathrm{N}$ sodium hydroxide. This component could also be detected in hydrolysates of ${ }^{35} \mathrm{~S}$-labelled T. utilis ${ }^{2}$.

We ourselves have reported recently on a feeding trial using the soluble fraction of proteinoid. In further experiments the water-insoluble fraction of proteinoid was collected and administered to a rat. The male rat had a weight of $85 \mathrm{~g}$ at the beginning of the experiment. The animal was kept in an air-tight cage in which a separate collection of urine and fæces was possible. The air passed through the cage by suction was filtered through traps to remove gaseous metabolites from the air.

The rat received food and water ad libitum. The diet consisted of 86 per cent maize, 10 per cent skimmed milk 